\title{
The Peloponnesian War, the Spanish Requirement and the Clash of Civilizations: An Application of Plato's
}

\section{Theaetetus}

by Wendy C. Hamblet

This paper challenges the notion of "civilization" as focal to, and originative of, the problem of suffering in the world, a legacy that continues to betray its heritage in the third millennium of the Common Era. The current global crisis of terrorism is, on both sides of this confrontation, being posed as a war of "civilizations." Both sides, the terrorists and the current American administration and its allies, argue for the righteous, divinely-ordained nature of their cause and the demonic nature of their infidel enemy. Both legitimate their violences by claims of superior "civilization" and both cite the god as in their "civilizational" court.

These hyper-religious and essentialist terms have not been rallied in the political arena of the world for some centuries. In fact, they find their precedent in the "Spanish Requirement" of 1513. This was named the "requirement" because the Spanish conquistadors were "required" by royal law to read it to their indigenous victims, before they set about their wholesale slaughter and enslavement:

\begin{abstract}
We ask...that you acknowledge the Church as the ruler and superior of the whole world....But if you do not do this, and maliciously make delay in it...we shall powerfully enter into your country, and shall make war against you in all ways and manners that we can, and shall subject you to the yoke and obedience of the Church and of their highnesses. We shall take you, and your wives, and your children, and shall make slaves of them, and shall sell and dispose of them as their highnesses may command; and we shall take away your goods, and shall do you all the mischief that we can, as to vassals who do not obey, and refuse to receive their lord, and resist and contradict him. And we protest that the deaths and losses which shall accrue from this are your fault, and not that of their highnesses, or ours, nor of these cavaliers who come with us.
\end{abstract}

This passage exemplifies in its clearest form how the most wanton violences can be perpetrated upon innocent civilian populations without risking the bad conscience of the agents: reconstruct the victims as "uncivilized infidels." Whether the goal is the acquisition of resources or cheap labour, the forced recruit of religious converts or simple territorial expansion, the worst crimes against humanity can, and have been, effectively justified by reconstructing the enemy as demonic and their slaughter or wholesale containment (in internment camps, slave ships or lagers) as politically necessary and indeed conducive to the greater good of humankind. Claims of superior civilizational status and divine support for the mission, however bloody, have traditionally proven very convincing. Today, most people believe they can clearly see when injustices of this type are being perpetrated and, when they do recognize them, they see their violence-legitimating logic as a perversion of the benevolent aims and humanizing processes at work in "civilizations" at their best. However, I propose, in this paper, that we take very seriously the fact of the violent origins of culture, religion and politics, generally cited as the essential features of "civilization," and entertain the fact that, though civilizations no doubt exist in more and less benevolent forms, the more benevolent forms remain the exception and not the rule. I might broadly found this no doubt scandalous claim on the wealth of anthropological theory that names love and friendship and other benevolent forms of human interaction as late "perversions" of the more fundamental, more "natural" urges toward intraspecies violence.

Ethologist and philosopher, Konrad Lorenz, writing in the sixties, pricked the pride of the "civilized" world with his discomfiting revelation that, in the evolution of the human species, murder and cannibalism came first, with "grotesque" perversions of the adaptive instincts of intraspecies aggression leading the maladaptive way, and love, nurture and friendship evolving only much later, as hyper-aggressive, antagonistic power displays evolved into rituals of redirected aggression, and eventually led to the development of rituals of appeasement and submission. We can trace this embarrassing legacy into our cultural, political and religious traditions, all of which, according to cultural anthropologists, find their birth in murder rituals, where aggressive instincts find their outlet in being projected onto markedly different others-the large carnivore prey of the Paleolithic hunt, the pharmakon in the ancient Greek polis, the cripple or the village idiot in Medieval towns, or any unlucky stranger who may, at any time, wander into the midst of a discordant community.

I have said that I might found my claim of the quasi-pervasive violence-legitimating logic by reference to the extensive work of cultural anthropologists. I might equally well call upon Freud to remind us that aggression arises from frustration of the sex drive and periodically breaks through the dam of inhibition and spills out murderously in every direction. However, in this paper, I shall simply assume the dark origins of human civilization and the murderous roots of cultural codes, religious traditions and economico-political systems, and shall argue that those dark origins reveal themselves starkly in the vision of justice Socrates attributes to the non-philosopher. I shall return to the cultural and political birthplace of the Western world, to the first superpower, Athens, to expose the traces of archaic murder rituals in the easy sacrifice of innocents to the political vision of justice.

At that first Western triumph of "civilization," whose political and cultural legacy I claim lingers intact in modern understandings of justice, I read, in the philosopher's harsh condemnation of the political heroes of the day the parting of the ways between the philosophico-ethical life and the politico-religious life of the state. That parting, I contend grounds the imperialistic logic that has endorsed the colonialisms of previous centuries and the neocolonialisms of capitalist democracies of the West, and that culminate in the shameless resource-exploitation and debt-enslavement levied by the "First World" over Third World peoples today. The heroic ethos has provided the logic for legitimating violences--against the poor of our own communities and against alien others--because the distinguishing difference that marks the "best" (aristoi) as more worthy and more deserving than others rests upon the assumption that moral worth resides in nobility of birth (god's way of choosing the best) and the possession of "old money." The corollary of this assumption, the moral inferiority of the poor and ignorant masses, that finds its clearest modern expression, not simply in the "faith-based initiatives" that feed the poverty-stricken only after they have dragged their "sinful" carcasses to church.

The parting of the ways between the philosophical and the political has also led to the unfortunate situation where the philosopher has abandoned her duty as midwife and gadfly, and taken up a reductive philosophical role in the ivory tower of the academy-confining herself to the lofty climes of an arid intellectualism. I offer this reading of the practice of modern philosophy not merely as a criticism of ethically barren intellectual elitisms, but in celebration of the few lonely philosophical voices that are currently being raised in these very difficult, ethically desolate times, when politics and religion seem to have gone utterly and shamelessly mad in their imperialist aspirations. Brave voices are seducing their disheartened colleagues from the safety of their towering perches to resume their more urgent and appropriate labours in the world.

Plato depicts Socrates underscoring, in many dialogues from the Gorgias to the Republic to the Theaetetus, the difficulty, nay the hopelessness, of achieving justice in the state when power remains in the hands of the non-philosopher. Plato appreciates the urgency of this problem because he had witnessed in his youth that those untrained in the philosophical art were easily corrupted by the temptations of power and wealth. Plato had witnessed the fall of Athens, but, for him, this fall is moral not political. In keeping with Socrates' dictum that no man can harm a better man, he sees Athens' decay not in its loss of political hegemony over Hellas, but in its loss of the moral high ground, both within the city, and in its relations with its neighbours and allies. When Athens massacred the men and enslaved the women and children of the friendly and virtually defenseless island of Melos, it had given up all pretence of justice and had become an outright tyrant-in modern terms, a rogue and terrorist state. 
the moral, political and intellectual authorities of the city, they reckoned, undermined the moral foundations of the state by placing in question its moral codes. 1 The Apology composes Socrates' response to these charges, but the Gorgias composes Plato's critique of the perverted vision of justice that led to this sorry sacrifice. Here, he has Socrates retaliate for his foul murder by launching a relentless and harsh attack against Athens in the heart of its hypocrisy, an attack aimed at its most renowned political heroes-Miltiades, Themistocles, Cimon, and Pericles. In stark distinction from the historian's vision of Athen's "fall" from greatness (Thucydides sees the collapse only through its military lens, in the lack of adequate leadership after Pericles), the philosopher charts the "fall" of Athens from its earliest signs of moral decay. Long before the leaders of Athens abandoned all pretence of pursuit of justice in the context of their worldly affairs, they ceased to exercise "right conduct" in the context of their personal and political lives at home.

Socrates' interlocutors in the Gorgias, like Plato scholars for millennia, are shocked by Socrates' unrelenting and harsh condemnation of Athens' most illustrious heroes. The shock comes about because the historian, Thucydides, has eulogized the long period of their rule as a chronology of unparalleled triumph. Miltiades and Themistocles were the architects of the two renowned battles between the Greeks and the Persian invaders. In both cases, vastly outnumbered by the well-armed aggressors, Athenian and Plataean armies saved all of Hellas from tyranny and enslavement. Miltiades crushed the invading forces of Darius in 490 B.C.E. at the famed Battle of Marathon, and, ten years later while Xerxes ravaged Attica, and advanced all the way to the Acropolis of Athens, Themistocles crushed the invasion when he destroyed the mighty Persian navy at the Battle of Salamis.

Themistocles is also praised in the histories for having shown wisdom of foresight in convincing the Athenian Assembly to invest its profits from the newfound silver mine at Maronea in building ships and dockyards and transferring the Athenian naval base to the fortified peninsula of the Piraeus. Cimon, Miltiades' son, was also a renowned hero, defeating the Persian navy at Eurymedon River in 466. Athens finds its pinnacle of greatness in Pericles. The reputation of Pericles is unequalled: Pericles led war-torn Athens to her civilizational peak, promoting her wealth and her culture throughout Hellas, investing in vast rebuilding projects that made Athens the jewel of Hellas.

With this heroic and valiant civilizational "history" intact, many scholars have had great difficulty in understanding Socrates' relentless disparagement of these heroes in the Gorgias. From 455e through 456a, 503cd, and again at 516d through 519a, Socrates mercilessly and relentlessly attacks Athen's historical champions. However, in that dialogue, in the testimony of Callicles, we have our earliest witness of the politician's worldview, a vision of reality posited as starkly dichotomous to that of the philosopher. The philosopher, by self-definition admits of humility: philos sophos, a lover or desirer of wisdom, distinguishes himself from sophos, the wise person or sage. Philosophical wisdom, after Socrates, resides in the knowledge that humans cannot know anything for certain, for wisdom is the property reserved for the gods. Callicles, on the other hand, claims in the Gorgias that he knows the very logic that rules the cosmos: he speaks for a "natural justice" (488b) when he argues for a realist politics:

In my view nature herself makes it plain that it is right for the better to rule over the worse, the more able over the less. And both among animals and in entire states and races of mankind it is plain that this is the case-that right is recognized to be the sovereignty and advantage of the weaker over the stronger. (482e-483d)

"Might is right" is the "natural law" that is the politician's maxim. Ironically, Plato has Callicles cite for his example of this "natural justice" not an Athenian hero, but the Persian aggressor to Hellas, Xerxes. Athens, like the Persian tyrant, prospers by adherence to the "natural Law" in her dealing s with the Isle of Melos. Thucydides records the logic used to justify in advance the mass slaughter of the men of that island and the enslavement of its women and children (because the Melians refused to join the Delian League and pay tribute to Athens' treasury). Before the slaughter, the Athenian voice argues:

you know as well as we do that when these matters are discussed by practical people, the standard of justice depends on the equality of power to compel and that in fact the strong do what they have the power to do and the weak accept what they have to accept. (The Peloponnesian War V. 89)

The Athenians, at the height of their vicious imperialism, mirror Callicles' vision of reality, and extend that vision to include the gods as complicit in this "natural violence."

Our opinion of the gods and our knowledge of men lead us to conclude that it is a general and necessary law of nature to rule whatever one can. (V.105)

Battles make for great stories. History renders truth from the perspective of the victor, charting justice as the reality of human triumphs-in the rise and fall of the tides of political and military might and in the riches amassed in their coffers. But the philosopher understands justice as a higher reality that provides a model for human behavior. Justice is often corrupted by wealth and power. Socrates's discerning eye is critical of Athens's heroes because he sees corruption, not wisdom, in the graft, nepotism and extortion that enriched the four great heroes of Athens and their families and friends, first from Athens's public treasury and later from the treasury of the Delian League. For the careful observer, corruption is already subtly evident in that great eulogy of Athenian power and superiority, Pericles' Funeral Oration.

The Athenians traditionally placed highest value in the virtues of sophos (wisdom) and sophrosune (temperance). Wisdom was loved, as it could foster the right thinking that manifests itself in right conduct-justice. But wisdom can also lead one astray and make one big-headed. The Greeks had a vast wealth of mythical and tragic testimony warning of the greatest crime against the gods, hybris. Hybris was punished by a relentless nemesis that could plague a family with generations of pollution. Sophrosune, on the other hand, could never be corrupted; one could never have too much temperance. Sophrosune was loved because it evoked humility and restraint against the ontological backdrop of the divine. Sophrosune warned against the overblown pride and arrogance, the hybris, which blinded human beings to their limits and landed them in ultimate ruin. In Pericles' Funeral Oration, as he eulogizes the greatness of Athens--its wisdom, its wealth, its honors and its power, won in celebrated battle on the land and the seas of Hellas, the one thing that is conspicuous in its absence is the virtue of sophrosune. By the time of its military peak, at the pinnacle of its power, Athens had already forgotten its own best self, its own most valued virtue, its time-honored understanding of goodness.

In the Theaetetus, we are shown how hybris is born in individuals in the adoption of faulty ideas (wind-eggs), how it grows into a feisty brat in hardened dogmatic opinion, and how it finally fulfils itself in mature tyranny. The dialogue charts the development of hybris as a function of mistaken perceptions, wrongful "seeings" of the good. In the philosopher's worldview, where the gods are just and people always seek the good to the best of their ability, it is the failure of perceptions to bring justice appropriately to sight that is blamed for the sufferings and evil in the world. The philosopher can see what the non-philosopher misses: that the way that the powerful view justice itself composes the integral problem for justice, where justice signifies not "the natural right of the powerful" evident in the tyranny of nature, but a harmonious state of human soul governing individual excess, a harmony exemplified in the peaceful coexistence of differing gods mutually restricting their distinctive powers and respecting individual timē (honor), a harmony that orders the heavens in perfect allotments of time and space, each keeping to his own domain and observing limits with respect to the others, a harmony that extends over the vast cosmos, bringing all soul into communion.

It is easy to see, in the beauty of these utopian visions, how the philosopher might be tempted to slip away into an arid intellectualism that ignores her duties in the world. But Theaetetus demonstrates why it is so important that one get right all aspects of the philosophical task. In the Theaetetus, Plato addresses the question of correct seeing when he has Socrates investigate "knowledge" with the young mathematician Theaetetus. The dialogue is ostensibly a lighthearted, leisurely investigation of the meaning of a simple term (a term of particular importance in the intellectual community); Socrates tempts the young Theaetetus to "come and play" his philosophical game. However, this lightness is only illusory, an eidolon or phantom reality. When we set these playful inquiries into their proper context, against the backdrop of the outer "frames of reality" that enfold the dialogue-the impending death of an old and war-wounded Theaetetus, the troubled recall of a now long-gone Socrates, the collapse of the great Athens into tyranny-this "playful" inquiry gains dark seriousness.2

The inquiry into correct knowledge as appropriate "seeings" begins before Socrates is introduced to the young Theaetetus. The boys' mathematics teacher, Theodorus, has stated that he brings the youth to Socrates' attention because the boy is "like Socrates." The boy is not Socrates, and yet his appearance is like that of the old philosopher (snub-nosed and rather ugly). It soon becomes apparent that the boy's nature (quick-witted yet humble, slow to anger but quick to learn, courageous yet gentle in character) is, like that of Socrates, contradictory to his ugly appearance. Socrates calls the boy over and states that Theodorus must serve as the "measure" (metron) of the likeness between the two. Theaetetus will be tested to determine whether Theodorus' vision of reality is true and good or whether his measure of likeness between the two is a misguided apparition. Theodorus refuses the position of metron, passing the task back to the philosopher-"You will see for yourself," he tells Socrates. 
the task of philosophy. The first is the image of the midwife at 148a \& ff., the second, that I shall name the "lofty spectator," arrives at $172 \mathrm{~d}$ ff. Throughout the dialogue, we witness the performance of the first, as Socrates offers to the boy the "potions and incantations" that evoke from him three philosophical "births" and then the old philosopher tests each new "birth" to determine whether it is a real and live baby truth or an eidolon, a deceiving apparition. It is not until we follow the misconceived labors that we see the need for the second image of philosophy's task.

Theaetetus begins humbly, deferring to traditional authority: Protagoras has said that "Man is the measure (metron) of all things." So knowledge, reasons Theaetetus, is a matter of perception. According to this doctrine, what appears (phainetai) is, or seeing gives being. Socrates praises Theaetetus' good beginning, but proceeds to "test the baby." If seeing gives being, then when I look at something, covering one eye, I find myself caught in the discomfiting paradox of something's simultaneously being and not-being what I name it to be; what appears both is and is not! The implication of this misconceived definition of knowledge: what appears within the compass of the naming of a thing by a perceiving subject is also not-being in regard of that which it is named as being.

It is significant that Theaetetus happily gives up the baby as misconceived and moves on to a second birth. If we name things as we see them, knowledge must be simple opinion. Socrates proceeds to measure the offspring once again. If knowledge is opinion, and each sees things from his own perspective, then all must be opinion. But if opinion is knowledge, then all opinion is true, and no one can be named wrong in his perceptions of things. This leads to the discomfiting paradox that the wise man whose pronouncements have given rise to these births, Protagoras himself, is only expressing an opinion, of equal validity to any fool's belief.

This is not simply a problem for Protagoras, whose wisdom, with his logos, has fallen into question and whose remunerations have thus fallen into risk, but this measuring of truth has brought into focus an ethical problem that arises when all opinions are given equal validity. Socrates concludes the test: Just as whatever any person names as "wholesome" for itself may or may not be so, similarly "whatever any state makes up its mind to enact as lawful for itself" is equally risky in truth. That is why, concludes Socrates, recognizing the risk, most states rest upon consensus of opinion.

In right or wrong or matters of religion, people are ready to affirm that none of these [laws] is natural, with a reality of its own, but rather that the public decision becomes true at the moment when it is made and remains true so long as the decision stands. (172b)

The philosopher sees that perceptions of justice are often misconceived and, when they are, they can easily fulfill themselves in bloody ends. When any man or any state can name things just as he/it sees them, justice itself has been forfeited. That is precisely why human communities, in the absence of universal agreement as to what is right, poll their varied collective opinions to place limits upon their own excesses, limit their individual hybris for the sake of the continuance of the whole. But, whatever the form of that whole, be it tyranny, monarchy, oligarchy or democracy, and whatever the content of the laws, whatever their value in effecting justice among the citizens of the communities they address, one fact remains, and that fact haunts the rest of the discussion and lends that "playful inquiry" a sudden urgency: the state is dedicated to nothing beyond its own continuance, and the laws of the state serve only that end. A state has nothing to do with justice; it owes nothing whatsoever to its citizens; it owes nothing to alien others. In the case of the state,

whatever name the state may give it, advantage is surely the aim of its legislation, and all its laws, to the full extent of its belief and power, are laid down as being for its own best profit. (177e)

It is the urgency of this ethical problem that turns the dialogue from the matter of personal fulfillment, expressed in the birthing logoi of the young Theaetetus, and toward the discussion of justice in the direct and urgent monologue of the old philosopher. Justices' multiple renderings in individuals and in states, and the implications of those multiple renderings for less powerful citizens and for less powerful, alien states necessitate a second image of the philosopher's labors, born of a rigorous comparison with the non-philosopher. Socrates employs for his example of the non-philosopher the lawyer advocating for his paying employer in the courts of law (but he could as easily have employed the image of the politician lobbying for an unjust war in the assembly). The non-philosopher is something of a "likeness" to the philosopher because he too applies the "potions and incantations" of persuasive logoi. But, where the philosopher is free to play at his leisure, following the argument wherever it may lead, the non-philosopher is bound by a purchased loyalty to his employer, he is bound by his reputation as a persuader. He takes no interest in the truth, but argues what he is paid to argue, to convince the judge standing over him, to impress the audience (for the sake of future employment), and to bring about the verdict that he has been paid to effect. And this he must do in a restricted time (a single day was the maximum length of an Athenian court case). It is for these heavy restrictions that Socrates names the non-philosopher a slave.

Then Socrates tells of the philosopher on his lofty perch high above the world, regarding the wholeness of things, cut loose from the constraints of time and place, free from the local loyalties that can cloud the judgment and impair the vision. The logos of the philosopher can wander free across the orderly heavens where harmony reigns supreme. That loftier vision permits him to see that the right motive in earthly actions, be they laws or persuasions or negotiations with allies or enemies, "is not that one should seem innocent and good," but that one should truly be so (176c).

What we witness in this shift from the stuffy confines of the courtroom to the lofty heights of philosophical vision is that distance is necessary to correct vision. Myopia is morally dangerous. One must step back from one's own city, one's own loyalties, to distinguish between seeming goodness and real, between wisdom and excellence of the genuine sort, and blindness and baseness of false opinion

Violence knows no territorial borders, no temporal or cultural boundaries. It extends across linguistic margins--from English to German to Arabic to Swahili to Spanish--in a logic extensive of the human world that presents no translation difficulties whatsoever (though one might argue that the languages of white Europeans has special claim as the mother tongue to slavery, colonization, conversion at gunpoint, and the mass slaughter of indigenous peoples).

Repression, enslavement and mass slaughter of innocents has been a practice of "civilized" human communities since those communities first arose. Like Lorenz, Socrates argues that overblown aggressiveness is not "natural" as many contend, but a perversion of the higher "human" instincts, and the natural just order of things. Socrates argues that the aim of states is their own best interest and profit. That aim is embedded in civilization as such, in the cultural codes, in the economico-political traditions and in the laws that regulate the behavior of its citizenry, and configure its worldly conduct. Thus it is that the greatest crimes against humanity have historically been perpetrated precisely in the name of the good, with the blessing of the god, and in claims of the superior civilizationary status of the aggressor.

If a true "axis of evil" exists in the world, it resides, as a very "human" phenomenon, somewhere within the triad of religion, politics, and suffering. Suffering itself is "evil." To inflict it upon others is another and worse. But perhaps worst of all is the logic, employed consistently in modern politics and fundamental to the worldview of each of the three "Great World Religions," that permits alien others to be named unworthy "infidels" and that configures cultural/racial difference as a difference in degree of "civilization." This logic, still in extensive use in the modern era, composes the most archaic and persistent "evil" that, historically, has underlay, and has been called upon to justify, the cruelest and most extensive violences levied upon peoples of the earth.

1 Socrates' real crime, as he rightly points out in the Apology, had been to disrupt the dogmatic self-assurance of its nobles (aristoi means both "noble class" and "good"). His nagging insistence that they clarify their terms, an insistence encapsulated in his relentless questions "ti estin;" (What is it?) and "pos legeis;" (How do you say it? What do you mean by these sayings?) highlighted the fact that the very words and concepts in terms of which the moral authorities of the polis described their actions and justified their worldly behaviors had broken loose from their social anchors. That is, Socrates exposed the moral bankruptcy of a political system that boasted democratic values while tyrannizing its poor and its allies and neighbours.

2 The significance of these metaphors of play and leisure will become clear in Socrates' distinction between the non-philosopher's work and that of the philosopher at 172d ff. 


\section{Selected Bibliography}

Bloch, Maurice. From Blessing to Violence: History and Ideology in the Circumcision Ritual of the Merina of Madagascar. Cambridge. U. K.: Cambridge University Press, 1986.

- Prey into hunter: The Politics of Religious Experience. Cambridge. U. K.: Cambridge University Press, 1992.

Burke, Charles. Aggression in Man. Secaucus, N. J.: Lyle Stuart Inc., 1975.

Burkert, Walter. Creation of the Sacred: Tracks of Biology in Early Religions. Cambridge, Mass.: Harvard University Press, 1996.

- Homo Necans: An Anthropology of Ancient Greek Sacrificial Ritual and Myth. tr. Peter Bing. Berkeley: University of California Press, 1983.

- Structure and History in Greek Myth and Ritual. Berkeley, Calif.: University of California Press, 1979.

Christie, Kenneth, ed. Ethnic Conflict, Tribal Politics: A Global Perspective. Surrey, U.K.: Curzon Press, 1998.

Daniel, E. Valentine. Charred Lullabies: Chapters in an Anthropology of Violence. Princeton, N. J.: Princeton University Press, 1996.

Dillistone, F. W., ed. Myth and Symbol. London, U. K.: S.P.C.K. 1966.

Dunne, John S. The City of the Gods: A Study in Myth and Mortality. Notre Dame, Ind.: Notre Dame Press, 1978.

Eller, Jack David. From Culture to Ethnicity to Conflict: An Anthropological Perspective on International Ethnic Conflict. Ann Arbor, Mich.: University of Michigan Press, 1999.

Girard, René. Violence and the Sacred. tr. Patrick Gregory. Baltimore: Johns Hopkins University Press, 1979.

Hamerton-Kelly, Robert G., ed. Violent Origins. Stanford, Calif.: Stanford University Press, 1987.

Lincoln, Bruce. Death, War and Sacrifice: Studies in Ideologies and Practice. Chicago: University of Chicago Press, 1991.

Lonsdale, Steven H. Dance and Ritual Play in Greek Religion. Baltimore: Johns Hopkins University Press, 1993.

Lorenz, Konrad. On Aggression. tr. Marjorie Kerr Wilson. New York: Harcourt, Brace and World, 1966.

Lystad, Mary. Violence in the Home: Interdisciplinary Perspectives. Philadelphia: Brunner-Routledge, 1986.

May, Rollo. Power and Innocence: A Search for the Sources of Violence. New York: Norton and Co., 1972.

Shaughnessey, James D., ed. The Roots of Ritual. Grand Rapids, Mich.: B. Eerdman Publishing, 1973.

Wendy C. Hamblet is a Canadian philosopher, alumna of Brock University, Canada, and Pennsylvania State University, U.S.A. Hamblet teaches Philosophy (Genocide Studies and Contemporary World Moral Problems) at North Carolina A\&T University in Greensboro, North Carolina. Hamblet's research centers about the problem of violence, subjectivity, and identity formation. She is author of The Sacred Monstrous: A Reflection on Violence in Human Communities (Lexington Books/ Rowman \& Littlefield, 2004); Savage Constructions: The Myth of African Savagery ( Lexington Books/ Rowman \& Littlefield, 20o8); and co-editor (with Richard Koenigsberg, Library of Social Science, New York) of Psychological Interpretations of War (New York: Taylor \& Frances Peace Review, 2006). 